CZU: 811.135.1'1(478)(092)

https://doi.org/10.52505/lecturi.2021.05.02

\title{
SILVIU BEREJAN - LINGVIST ADMIRABIL ŞI CONDUCĂTOR ŞTIINŢIFIC ONORABIL
}

\author{
Dumitru APETRI \\ Institutul de Filologie Română „Bogdan Petriceicu-Hasdeu”, Chișinău
}

Rezumat. Academicianul Silviu Berejan, protagonistul articolului, e văzut de autor în câteva ipostaze: lingvist de marcă, conducător ştiinţific iscusit al cercetărilor de ordin filologic şi umanistic, promotor activ al limbii române în R. Moldova, personalitate sensibilă faţă de valorile cu adevărat ştiințifice şi binevoitoare în relaţii cu creatorii lor.

Cuvinte-cheie: lingvist admirabil, conducător ştiințific, promotoractiv, personalitate sensibilă, ştiinţe umanistice, nivel interpretativ, generalizări.

Abstract. Academician Silviu Berejan, the protagonist of the article, is seen by the author in several ways: a distinguished linguist, a skilled scientific leader of philological and humanistic research, an active promoter of the Romanian language in Republic of Moldova, a personality that is sensitive to the scientific and benevolent values in relations with their creators.

Keywords: admirable linguist, scientific leader, active promoter, sensitive personality, humanities, interpretive level, generalizations.

Aflarea mea în cadrul Institutului de Filologie al AŞM, în ultimele trei decenii de activitate a dlui S. Berejan, mi-a permis să-l cunosc pe dlui îndeaproape. Avea, pe bună dreptate, faimă de lingvist remarcabil şi o evidentă vocaţie de dirijor ştiinţific. Înalta cultură generală, de care dispunea, îi stimula pătrunderea adâncă nu numai în specificul şi esenţa fenomenelor lingvistice, dar şi în natura, particularităţile studiilor de istorie şi critică literară.

Am fost de mai multe ori martorul situaţiilor, când literaţii, în preajma discutării rezultatelor muncii lor, se gândeau la reacţiile ce puteau să parvină din partea distinsului lingvist. În anii '70, Domnia sa realizase o exegeză fundamentală şi unică în domeniul lingvisticii - „Echivalenţa semantică a unităţilor lexicale". Această investigaţie, care avea o tangenţă directă cu domeniul sinonimiei, îi permitea să se pronunţe competent despre unele aspecte ale investigaţiilor de ordin istorico-literar. Pe drept cuvânt se spune că munca scriitorului constă, cu preponderenţă, în alegerea sinonimelor. Deci, 
cel versat profund în această sferă dispune de o anumită libertate în judecarea şi aprecierea textului beletristic şi, desigur, a comentariilor respective. $\mathrm{Cu}$ astfel de calităţi a fost înzestrat admirabilul lingvist academician S. Berejan. S-a întâmplat nu o singură dată, când intervenţiile Domniei sale în dezbaterea aspectelor de ordin stilistic şi chiar istorico-literar se dovedeau a fi de o utilitate mai pronunţată decât considerentele unor literaţi.

În paralel cu evidenta vocaţie de lingvist, S. Berejan era înzestrat cu un incontenstabil talent de dirijor al cercetărilor ştiinţifice. Pe drept merit i s-a oferit în anii ' 80 postul de director al Institutului de Limbă şi Literatură al AŞM. În această ipostază, căuta insistent să evite editarea unor lucrări inoportune, adică, afectate de orientări ideologice nefaste sau neaduse la nivelul interpretativ cuvenit. Un exemplu: conform unui plan editorial al Institutului, spre finele anilor ' 80 , urma să apară partea a doua a volumului 3 al „Istoriei literaturii sovietice moldoveneşti”, care trebuia să reflecte starea de lucruri a contextului literar din segmentul de timp 1965-1985.

Vreo trei persoane dintre literaţi considerau că sunt riscante generalizările asupra unui proces viu, în continuă mişcare, metamorfoză, majoritatea însă opta pentru editare. Domnul director a aderat la opinia minorităţii şi a stopat acţiunea nechibzuită îndeajuns. Înnoirile simţitoare, uneori chiar esenţiale ale vieţii culturalartistice, provocate de Restructurarea gorbaciovistă, au confirmat pe deplin justeţea deciziei luate atunci.

În anii '90, domnul S. Berejan a beneficiat de avansări solide: i-a fost acordat titlul de academician şi i s-a încredinţat dirijarea Secţiei de ştiinţe umanistice. Aflându-se în această funcţie, a întreprins un şir de acţiuni care au îmbunătăţit substanţial activitatea ştiinţifică a filialei respective, dar, cu sufletul şi firea, a rămas ataşat profund, până la finele vieţii, de domeniul lingvisticii, de destinul limbii române. Concludentă în acest sens este participarea sa activă la elaborarea dicţionarelor explicative, etimologice, a manualelor universitare („Curs de gramatică istorică”, „Lingvistică generală”), a lucrării „Cuvântul şi lupta de idei”.

În final, mă îndeamnă firea să fac o mărturie ce mă priveşte personal. La absolvirea doctoranturii, am fost angajat la serviciu în sectorul „,Relaţii literare moldo-ruso-ucrainene”. Cercetam tema „Receptarea literaturii ucrainene în Republica Moldova în perioada 1924-1984”. Spre nedumerirea şi mirarea mea, rezultatele muncii înfăptuite de mine adeseori se pomeneau în contradicţie cu orientările sectorului. Îmi permit să reproduc câteva opinii personale şi argumentările contrare. Mi se reproşa mereu că subapreciez calitatea traducerilor realizate în republică până în anii '60. 
Reproduc câteva dintre constatările ce provocau opinii contrare: a) calitatea traducerilor efectuate la noi în republică până pe la mijlocul anilor '60 (cu mici excepţii) nu pot asigura o receptare adecvată a originalelor ucrainene. b) aşa cum au apărut, mi se spunea, populaţia le citea, erau declamate în scenă, figurau în manuale. Analizele ce le prezinţi trebuie să rămână pe masa d-tale de lucru, la sector să aduci concluzii în cheia prieteniei; a) versiunile din poezia şevcenkiană, ticluite în RASSM, nu sunt decât o propagare prin ruşine a operelor Poetului naţional al Ucrainei. b) e o exagerare. Şevcenko era cunoscut şi adorat în spaţiul transnistrean atât prin intermediul limbii ucrainene, cât şi prin traducerile din perioada interbelică. Această constatare i-a pus serios în gardă pe colegi, mi-au refuzat participarea la sărbătorirea aniversării a 160-ea de la naşterea marelui Cobzar şi au continuat să-mi citească articolele cu atenţie exagerată şi cu suspiciuni.

Alte opinii neacceptate de colegii mei (cu excepţia Alexandrinei Matcovschi): a) circulă la noi lucrări cu tematica raporturilor literare moldoruso-ucrainene ce conţin exagerări despre influenţa literaturii ruse şi ucrainene asupra literelor moldoveneşti; b) lucrările existente nu sunt chiar ideale, dar să nu uităm de o chestiune foarte importantă: ele au înalta misiune de a combate atacurile ideologiei capitaliste; a) nu de puţine ori se întâmplă că analogiile tipologice din anumite lucrări editate nu numai la Chişinău sunt prezentate eronat ca fapte de influenţă est-slavă; b) aici chestiunea e subtilă: nivelul interpretării depinde direct de pregătirea teoretică a autorului. a) noi, membrii sectorului de relaţii literare, nu putem asigura o cercetare eficientă a literaturii ruse din Moldova din cauza necunoaşterii realităţilor (Siberia, Tundra, Orientul depărtat) zugrăvite în scrierile lor etc. b) trebuie să conştientizăm cu toţii faptul că noi suntem nu numai o instituţie ştiinţifică, ci şi ideologică.

Când am văzut că opiniile, la care ţineam şi le consideram corecte, tensionează tot mai mult raporturile mele cu sectorul, am schimbat munca de cercetare pe cea de predare. M-am angajat la Institutul Republican de Perfecţionare a Cadrelor Didactice. Între timp, domnul S. Berejan devine director al Institutului de Filologie. Aflând motivele plecării mele, mi-a propus să revin şi să reiau activitatea ştiinţifică în oricare dintre sectoarele existente. La finele celui de al doilea an de muncă în calitate de lector, m-am întors la institut şi iată activez aici până azi. Pe parcurs domnul academician mi-a făcut şi o altă propunere, dar, din teama de a fi suspectat de lipsă de modestie, o las în anonimat.

Aşadar, regretatul academician Silviu Berejan, pe care îl comemorăm actualmente, întruchipa un înalt devotament ştiinţific, calităţi de dirijor iscusit al proceselor de cercetare, de promotor activ al limbii române în spaţiul urgisit de străini al Basarabiei, precum şi o personalitate ce manifesta multă bunăvoinţă faţă de colegii şi subalternii săi. 


\section{Referințe bibliografice:}

1. BAHNARU, Vasile, BEREJAN, Silviu. Cuvântul și lupta de idei. Chișinău: Știința, 1986.

2. BEREJAN, Silviu. Echivalența semantică a unităţilor lexicale (publicat în rusă). Chișinău: Știința, 1973.

3. BEREJAN, Silviu (în colab.). Lingvistica generală. Chișinău: Lumina, 1985.

4. BEREJAN, Silviu (în colab.) Curs de gramatică istorică a limbii române. Chișinău: Lumina, 1985.

Notă: Articolul a fost realizat în cadrul proiectului de cercetare 20.80009.1606.03 Contexte socioculturale autohtone şi interconexiuni europene în creația populară şi literatura cultă din Basarabia (sec. XIX până în prezent), Institutul de Filologie Română „B. P.-Hasdeu” al MEC. 